\title{
Speculative vertices, Ogun mythopoesis, and (the) fourth/further stage(s)
}

\section{Chike Okoye}

\begin{abstract}
Speculative vertices, Ogun mythopoesis, and (the) fourth/further stage(s)
Wole Soyinka's seminal essay, "The Fourth Stage: Through the Mysteries of Ogun to the Origin of Yoruba Tragedy" which appears as appendix in his collection of critical essays, Myth, Literature and the African World (1976), has been read and critiqued as an important work of myth, mythopoesis, tragedy and the Yoruba pantheon. To date, no meta-critical study has yet treated the essay as essentially speculative fiction, or as an invented model or construct for variegated possible future applications, or even as an authentic African futuristic artistic invention. This is important in present times as a resurgence of earlier genres and trends populate the literary world, thereby raising the need for underpinnings, connections, projections, and conflations such as this article presents. With the application of archetypal author-, text-, and context-oriented theoretical modes alongside historicity, this essay navigates and re-interrogates "The Fourth Stage" and its numerous critiques in the contexts of Afrofuturism and Africanfuturism, finding it a practical model for African futuristic mytho-cultural and literary productions. I also through this essay expose the multiple areas of possible applications of such inventiveness in the reappraisal and re-interrogation of the problematics and maladies of the postcolony. Keywords: Africanfuturism, speculative fiction, myth, mythopoesis, archetype, pantheon.
\end{abstract}

\section{Introduction: Speculative fiction(s)}

Raymond Coulombe's conditional "what if?", the impetus that informs and propels the spectral gamut of speculative fiction (Christion), is neither antipodal nor antithetical to verisimilitude. Paying homage to the boundarylessness of ontological existence and human imagination, new thoughts morph into words that create worlds surreal, yet appealing, birthing ideas that roam the range of science fiction, Afrofuturism, Africanfuturism, magical realism, legends, sagas, and myths. The chronological gradient in this listing is indicative and representative of epochs and attendant contexts. Coming from, and belonging to a common backcloth, speculative fiction is the cycloramic canvas, the effort and evidence of humankind conjecturing and extrapolating in an existential bid to understand and explain phenomena and produce desired worlds. Basically, any fiction infused with the supernatural, fantastical, and futuristic, suggesting alternative indices of existence-past, present, and future-from what is quotidian and, in extension constitutes the dream of a new earth and new heaven, is speculative fiction. Ikenna Dieke conflates mythmaking in theorizing speculative fiction in the possible deployment of elements of heroic fantasy in fashioning viable futures by arguing that "this heroic fantasy is expressed in the millenarian myth which, extrapolating from present milieu and knowledge, objectifies the hopes and fears of its time, creating infinite models of social possibility by which it evaluates the present" (284). Dike Okoro for his own part delineates the components of the concept. Okoro leans towards Africa, bringing into sharper focus the boundaries around Afrofururism and Africanfuturism; and beyond.

For Okoro in "Futuristic Themes and Science Fiction", "narratives by many African fiction writers whose stories incorporate characters and traits found in science or fantasy fiction [...] explore the supernatural, myths, magic and mystery" (379). Okoro's position draws from John Mbiti's stance that Africa's religious Weltanschauung is based on the existence of spirits, ancestors, and spirit beings (Mbiti 75). However, Okoro makes an important distinction between Afrofuturism and Africanfuturism - the former a la Mark Dery is about writings existing in America "essentially associated with black speculative fiction written by African American SF writers" (379); while the latter "is identifiable in works of fiction by first generation African fiction writers and the succeeding generations that follow their trail" (379).

Chike Okoye is professor of poetry and postcolonial literatures, Department of English, Faculty of Arts, Nnamdi Azikiwe University, Awka, Nigeria. Email: cb.okoye@unizik.edu.ng

(D) https://orcid.org/0000-0002-5210-1079

D0l: https://doi.org/10.17159/tl.v58i2.8965

DATES:

Submitted: 28 October 2020; Accepted: 22 June 2021; Published: 14 October 2021 
Nnedi Okorafor, who coined and started using the term "Africanfuturism", is of the position that it "is a sub-category of science fiction. Africanjujuism is a sub-category of fantasy that respectfully acknowledges the seamless blend of true existing African spiritualities and cosmologies with the imaginative". She states this in her Nnedi's Wahala Zone Blog and continues in explication that, though Africanfuturism is similar to Afrofuturism, the difference lies in the former firstly being more rooted in African culture, history, mythology, etc., before seeping into the Black diaspora. For Okorafor, though Africanfuturism is concerned with visions of the future and technology, it is not too occupied with "what could have been" but more with "what is and can/will be". It is also aware of and projects "what has been". Its center is Africa, though it often extends beyond. In exemplary extrapolation, Okorafor puts forth: "Afrofuturism: Wakanda [the kingdom of Wakanda in the film Black Panther] builds its first outpost in Oakland, CA, USA. Africanfuturism: Wakanda builds its first outpost in a neighboring African country". In furtherance, she is of the view that Africanfuturism does not necessarily include fantasy; the fantasy is set in the future or involves space explorations and technology, etc., making it more of science fiction than fantasy. Importantly, by virtue of its make-up, Africanfuturism will naturally have elements of mysticism that are authentically African and not made up. However, she admits that certain works "are both Africanfuturist and Afrofuturist, depending on how they are read".

Interestingly, in "The Mirror of Afrofuturism" Samuel Delaney tries to dismiss the author clause in Afrofuturism's description- "what's needed for Afrofuturism is black characters in the future, whatever the race of the writer" (173) - and subsequently lists texts to buttress his position. He states further that "Afrofuturism is pretty much anything you want it to be and not a rigorous category at all" (173) and warns of the need to set up critical mirrors in delineating and theorizing on Afrofuturism, reminding us that the term "was coined by a white critic, Mark Dery in his 1993 essay 'Black to the Future" (173). Delaney reasons that, since whatever he writes as a black writer in the science fiction form is Afrofuturism, he still maintains that "historically 'Afrofuturism' is a white concept that does not hinge on the race of the writer" (179). Time, according to him, seems to have changed the reflective vertices of Afrofuturism given its "dubious", apparently non-racial/(racist) beginnings to its vaunted all-black/African affairs of the present. He emphasizes the fluidity and dynamism (akin to difficult seamlessness) in the concrete definition and description of the concept of Afrofuturism.

In her book Afrofuturism, Ytasha Womack informs us that some cases of Afrofuturism are basically "a total re-envisioning of the past and speculation about the future rife with cultural critiques" (20). However, on a transitory note to Africanfuturism, it is clear that Afrofuturism embodies black/Negro dominance in a science fiction base, while science fiction is almost always Caucasian/white-based but serves as a ready tool for both the sliver of Afrofuturism and the broader canvas of speculative fiction. As I will show soon, Africanfuturism as part of speculative fiction draws more from African mythological pasts (and presents) to blend with futuristic science. Rudimentary notions of myths as being designed to explain the nature and workings of the universe and as guides on necessary behavioral patterns for successful living, have been found originating in oral tradition; often including elements from legends and folklore. Myths and legends are the earliest stories recorded by people with legends originally based on historical happenings; albeit all of them being exaggerated and/or unreliable (Rosenberg xv, vi; Squire and Squire 2, 3; Akporobaro 48). Akporobaro's view that "myths are usually distinguished from legends in that they have less of an historical basis ... (and) that mythology (is) a body of related myths shared by members of a given or religion" (49), and Rosenberg's notion that myths are abstract constructions rather than "narrative tales or symbols of experience" (xxi), are both complementary in their respective informative and intellectual bents. Ivor Hartmann, as quoted by Jane Bryce, is categorical in this: "Most speculative fiction, be it fantasy, sci fi or horror, is firmly rooted in cultural mythologies" (3). Bryce states unequivocally that "(what in literature we now call speculative fiction) has its roots in African modes of storytelling that draw on myth, orality, and indigenous belief systems that lend themselves to the invention of personal mythologies [...]" (1). Alastair Niven describes Ben Okri's magical realism in The Famished Road as "[...] a perpetual story into which flowed the great seas of African dreams, myths, and fables of the world, known and unknown" and Alexandra Alter describes Okorafor's novels as novels in which "magic, ritual and secrecy are threads that $[\ldots]$ run through $[\ldots]$ a head-spinning menagerie of other-worldly spirits and deities drawn from Nigerian myths and legends".

D. O. Fagunwa's Forest of a Thousand Demons and Amos Tutuola's My Life in the Bush of Ghosts and The Palmwine Drinkard form the scribal urtext as copies of embellished oral tradition for the pioneer forebears of speculative fiction in Nigeria. To this duo could be added Elechi Amadi (The Concubine) and Cyprain Ekwensi (An African Night's Entertainment). Mark Bould mentions writers in Africa he regards highly as practitioners of African science 
fiction-Algerian Mohammed Dib (Who Remembers the Sea, 1962), South African J. M. Coetzee (Waiting for the Barbarians, 1980), Congolese Sony Labou Tansi (Life and a Half, 1977), Kenyan Ngugi wa Thiong'o (Wizard of the Crow, 2006), and South African Nadine Gordimer (July's People, 1981) (see Okoro 380). Okoro conflates speculative fiction with postcolonial writings: "Some [...] imbue neocolonial experiences with speculative narratives and tropes enriched with magic [...] Ben Okri's The Famished Road, Kojo Laing's The Woman of the Aeroplane, Zakes Mda's Ways of Dying, Syl-Cheney Coker's The Last Harmattan of Alusine Dunbar and Buchi Emecheta's The Rape of Shavi" (385).

In whatever mode or to whichever purpose- whether it is in the construct of a derivative meta-tale reflective of Prometheus' sacrifice for humanity, or precludes the ritual commemoration of solidarity by workers on May Day viz-a-viz the shot colleagues of 1841 Chicago (Ofeimun 31, 32), or African writers digging into their rich and fantastical oral or/and urtext to structure and position their writings-Kayode Afolayan's summary of the utilitarian values of mythology is germane. He posits Durkheim's traditionalist view that the purpose of myth is "to bind a society, create a structure governed by rules and habits", and Sorrel's modernist perspective that myth is "not to stabilize but to direct energies and inspire action" (188). Speculative fiction is not new in Africa. The stories handed down through generations which are still told today on the continent contain elements of fantasy and the supernatural and are engrained in the ontology. Its variant in the diaspora as Afrofuturism, which according to Elizabeth Hamilton is "the artistic and aesthetic choice to inject futurity, fantasy, and technology into the creation and discussion of cultural production in the African diaspora" (71), is only a testament to the original blossoming elsewhere. By all means of utilitarian value, Africa's intrinsic belief in its active ontology of archetypal inter-dimensional co-existence of beings—ogbanje/abiku, deities/gods, humans, ancestral spirits, liminal beings, etc. - is enough enabling background for literary projections of speculative tenor and texture.

\section{Situating the Ogun mythopoesis: The Soyinka angle}

Archetypal, comparative, textual, and contextual critical modes are applied in this essay; all couched in author-, text-, and context-oriented approaches. Historicities are also navigated in my concerns about speculative vertices and myth criticism; exploring and using the Yoruba Ogun mythopoesis as seminally interrogated by Wole Soyinka in "The Fourth Stage". Soyinka's essay essentially features Ogun, a Yoruba god who heroically bridges the gulf(s) of transition in the three planes of existence - the world of the dead, the unborn, and the ancestors-in order to ameliorate the primordial anguish of severance within the gods and with man. Ogun could essentially achieve this partly because his abode is the "liminal ether of the gods". The plan of this article is to launch from this springboard and extrapolate conflations and futures-just as our modern writers consciously appropriate ancient myths for their use.

Variants abound but the crux of the Yoruba pantheon mythology is about disintegration, re-composition, and anguish. In the beginning, an archdivinity, Orisa, was in the company of Orunmila, god of divination and wisdom. They descended into the primeval void to start creation under the auspices of Olodumare, the Supreme. Orisa had gotten himself a slave at the Emure market named Atunda. Soon after being acquired, he sought permission from Orisa to till a piece of land near the house, on top of the hill. His hard work impressed Orisa. By a quirk of nature, envy consumed Atunda and he planned to murder his master and subsequently rolled a massive boulder onto his master's back during one of his visits. The devastating result was the fragmentation on impact of the erstwhile wholesome Orisa into four hundred and one components-this number representing the entire Yoruba pantheon after reassembly by Orunmila, the agency of divination and wisdom.

This act of rebellion by Atunda/Atooda/Atowoda in breaking up the godhead and center of authority is hailed by Soyinka as a revolutionary move aimed at breaking the cycle of eternity and godly authority; made more poignant since Atunda was human. Again, Soyinka holds the dissolution as a momentous night of tragic becoming; the anguish suffered by the god and his votaries and his own soul-shattering ordeal later to be dramatically replayed in the passion plays of Sango and Ogun. A primordial severance with man was a cause of haplessness and frustration among the distraught gods and Ogun came to the rescue, breaking the jinx in creating a path to man. He crossed the inchoate void - the fourth stage-in order to achieve this and was thereafter elevated to king status both by his fellow gods and mankind. This offer of regency by gods and men he duly rejected but later succumbed to the relentless pressure of men - the people of Ire. Of course, his unique multi-valence reared its head, and he slaughtered his own men in a fit of his essence (Layiwola 22; Ebeogu 92, 93; Afolayan 189; Adu-Gyamfi 75, 76). 
Many variants of the crux of this story exist for contextually utilitarian purposes. Contrivance and appropriation are the keys and tools in play for Soyinka's character of the void, Ogun (the alter ego and clone of sorts of the Ogun of the Yoruba pantheon). This is because the character (Soyinka's personal god, muse, and kindred spirit) which he widely applies in his literary works and life in different conflations, vertices, and contexts, is the one already conveniently altered to reflect and retain his peculiar caprices on one hand, and on the other, primordial archetypal essence(s), respectively. His own Ogun has attributes that are easily identifiable and sometimes seamlessly inextricable from the other variants of the Ogun myth. Nevertheless, Soyinka's variant suits his purposes. The general and primordial Ogun was supposedly a man before attaining god status: fiery tempered, reckless, always drunk, jovial, kind, protector of the weak, enraged killer of his celebrants, destructive, god-turned-human, power-drunk god of war, god of metallurgy and harvest, and the unpredictable retributive one (Ebeogu 85-90). Afolayan's view is that "Ogun carries dual identities; primarily he creates yet destroys, he solves problems but fans machinations, he is a catalyst for peace and pandemonium [...] (he is also) a rescuer [...] a villain" (189-90). Olatunde Lawuyi enumerates his favorite soothing totems: wine, food, dogs, snails, and palm oil. He also recounts a scene when, out of a lack of attention at his arrival at a merriment scene, he draws his sword on the revelers. But, despite that, Lawuyi still calls Ogun "a leader". He goes further: "[...] Ogun is a hero or a deviant [...] a leader in the forest, a follower of Oduduwa at home; he can sleep with his superior's wife in the forest and lie about it at home" (135), effectively establishing Ogun's reputation as lascivious. Dele Layiwola sees Ogun as an artist: "if we assemble the gods in an aesthetic mould, Ogun always puts the finishing touch" (26) and quotes Bolaji Idowu for support: "As the master artist, it is Ogun who gives the finishing touch to the work of Orisa-nla" (qtd in Layiwola 26). It is Ogun's calcified strength and energies encrusted by his daring breach and bridging of the fourth stage that negatively resurfaces while he is king of humans at Ire. This shows that his human dimension is incapable of containing his demoniacs when unleashed. This is described by Soyinka: "At the first battle the same demonic energies were aroused but this was no world womb, no chthonic lair, no playground of cosmic monsters [...] (and) the divisions between man and man [...] (could not) be perceived by the erstwhile hero of the transitional abyss" (32). He also distinguishes between the serenity associated with Obatala by highlighting Ogun's profound sorrow: "There is no elation $[\ldots]$ nothing like the beatified elation of Obatala [...] only [...] a profound sorrow [...]" (32). The foregoing gives a good overview of the general and historical Ogun, preparing us for Soyinka's appropriated Ogun. Bryce has categorically stated that writers invert, appropriate, and invent myth and history in their productions by saying that "one of the tools [...] has been the invention of personal mythologies and the rewriting of history in the light of future realities" (10). There is ample support for this view on Soyinka and the Ogun myth. Ketu Katrak declares: "Yoruba myths that are used for tragic drama are always molded to comply with the purpose of Soyinka's tragedy" (32). Of his tweaking of Obatala and Ogun, he says: "Soyinka uses their [...] characteristics and transforms the two gods into symbols of his own concept of tragic experience" (41). He adds, in a sure tone: "Soyinka also alters Ogun's traditional role as god of iron and war, into "first actor [...] in the first art [...] tragic art"' (41). It is clear that he creates for a purpose and applies the speculative mode for a goal. By expanding and weaving the intricate threads to flesh out the Ogun character to suit his needs, he engages in the most utilitarian of inventions.

Odia Ofeimun believes that Soyinka consciously downplays historicity, or better still, "devalues the history to ensure that it does not interfere with the purposes of his myth" (60). He confines Sango to a relegated historical plane while elevating Ogun to mythical sublimity (Ofeimun 61) and touts the efficacy of this approach, especially when he writes: "Soyinka's reduction of the Ogun myth to a written, scribal, culture, made it possible for me to appreciate and subscribe to the historicity of Ogun" (23). Having compared history and Soyinka, Afolayan declares that "Soyinka's mythopoesis must be at variance with the 'authentic' or popular versions of the Ogun myth" (190), while Yaw Adu-Gyamfi simply states that "Soyinka's version of the mythical background to this summary in Myth, Literature and the African World is quite different from other anthropological accounts by scholars such as S. A. Babalola and Sandra Barnes" (75). Adu-Gyamfi lets us understand that the reconstruction of the myth entails tweaking aspects of the protagonist-Ogun. He also hints at Soyinka's coalescence of the different variants of the histo-mythological Ogun in his "privatist mode and from the universalist-individualistic outlook" (Chinweizu, Jemie, and Madubuike 235). Afam Ebeogu and Layiwola also agree that Soyinka creates an Ogun from the original pantheon Ogun that suits his varying needs. Soyinka himself admits this. Biodun Jeyifo quotes a conversation between Ulli Beier and Soyinka in which Beier asks Soyinka: "This image of Ogun has accompanied you through your later writing; but it has been said that the Ogun of your play is a rather personal, 'unorthodox' Orisa - that 
in fact, you created a new kind of Ogun?" To this, Soyinka replies, "You create Ogun", "Hmmm [...] that is true", and "Yes, indeed".

The evidence and Soyinka's admittance might appear trite for the informed. However, it is necessary in the course and concern in the writing of this article. My posture is about possibilities of creation, of futurism, of Africanfuturism from the wells of myth and mythologies indigenous to Africa in our conflations of the speculative as constructs for society and its vicissitudes. These vertices as exemplified by the Soyinkaresque Ogun mythopoesis are not mere plasticization of aesthetic license but have utilitarian value - and there is evidence, too, to that effect. Soyinka's predilection for action, especially revolutionary action bordering on destructive violence, albeit aimed at positive change and creativity/recreation, is partly birthed on the cusp of concept and idiosyncrasy. He extols Atooda, inverting his treacherous rebellion into revolutionary drive as catalytic for reversing hegemony and complacency. Layiwola avers when he says that "purposeful action, as both creation and destruction, becomes a veritable leitmotif in Soyinka's most profound art" (23). Again, Soyinka is obviously aware, as is evident in his works and worldview, that traditional civilizations do not find a base in history or historicism, but are better off with mythic signposts and models that guide their existentialism, as evident in his downplaying of history in favor of enhanced mythology which he roundly applies in his art. In a commendable and ingenious aesthetic twist, he yokes his Ogun's ancient forge responsibilities and present automobile oversight functions together (Ogun is god of the road and iron and automobiles are made of iron), thereby consolidating an organic link with practical mythopoesis. It is important to note, however, that whatever the altruistic or artistic reasons or use for his mythopoesis, it has been viewed by some with skepticism. Afolayan's view is that "Soyinka's deployment of the Ogun myth has generated a lot of concern with the common denomination bothering on the utility of the Ogun myth" (190).

It is important to note that there are opposing and divergent views to Soyinka's ideas. Canice Nwosu believes that Soyinka's theory is less suited for performance analysis. He says that "the earliest theories of J. S. Mbiti, Wole Soyinka and Ngugi wa Thiong'o that ushered in African postmodernism tilt more towards traditional criticism of text than performance analysis" (101). He is also of the view that these theories are not African enough because "the reference point of most modern African theorists remains the precepts of European scholars" (118). He further avers that these theories lack basic theatre approach, are designed for "use in academic institutions", and are more like "English and literary studies theories" (138). Ofeimun delineates reactions to Soyinka's essay into those who accuse him of selling out to the West; those who believe that, in his bid to retrieve the African worldview, he has overdone it; and a third position in which he quotes Anthony Appiah: "the Soyinka whose account of Yoruba cosmology is precisely not the Yoruba account; the Soyinka who has taken sometimes Yoruba mythology, but sometimes the world of a long-dead Greek, and demythologized them to his own purposes, making of them something new [...] private and individual" (37). Femi Osofisan, also quoted in Ofeimun, outrightly rejects the "imperialistic sway" of Soyinka's Ogun, saying that Soyinka's "recourse to the gods was retrogressive", choosing Orunmila - another of the Yoruba deities, in charge of divination - as better suited for service in our times (88). Of course, some discomfort should be welcome in creation, just as Soyinka's Ogun as pathfinder experienced in wading the void. Soyinka does not shirk his path and resolve as the need for utilitarianism (through invention in his case) of the arts is not debatable. He maintains that "Yoruba traditional art is not ideational however, but "essential" (22).

On the basis of cultural relativity and ethnocentrism, the background to Ogun and his mythopoesis is a pointer that civilization is a relative concept. Lawuyi opines that it is both "an indication of religious insight and the expression of a cultural doubt about the supposed backwardness of Africans" (128). This, of course, makes vague allusions to the vaunted Nietzschean Birth of Tragedy, a guiding counterfoil and evidence of equipoised cultural relativity with "The Fourth Stage" of Soyinka. An interesting and revealing aspect of Ogun is in his apparent use in the portrayal of historical internecine strife the ancient Yoruba are known for-Ogun in this case becomes an abstract indicative index and corroborating history. Lawuyi puts it this way: "Ogun's uniqueness as a symbol of war lies in the internal strife and tensions not uncommon among the constitutive subethnic Yoruba" (129). Oyin Ogunba has this to say on Soyinka's use of Ogun as a personal symbol:

Soyinka has discovered his god, Ogun, who will henceforth be the main source of inspiration not only in his plays but also in his poem "Idanre" and his novel The Interpreters. In A Dance of the Forests, the duality of Ogun's character (destructiveness and creativity) is already appreciated, but the emphasis is still on his negative side [...] in "Idanre" he begins to dream of Ogun's creative and regenerative side dominating his less attractive, less humane qualities. (102) 
This dream of a more positive side later appears in Ogun Abibiman and Ebeogu confirms that "The arrival of Ogun Abibiman bears out Ogunba's anticipation of this more positive side of Ogun in Soyinka's works" (93). Further textual application of Ogun to enhance the plot and drive messages home could be found in The Road where drivers who ply the roads worship Ogun as god and guardian of the road. There are cases of Ogun's possession (Murano) being knocked down by Kotonu's lorry (made of metal, Ogun's totem), and the assignation of Murano by the Professor as a tapster of palm wine-Ogun's favorite brew. The cyclic dynamism and tautness of the Ogundrenched plot drives home the message more effectively. Other uses of Soyinka's speculative efforts range from the compactly arcane applications of the Ogun mysteries and attributes as found in Kola's canvas in The Interpreters (qtd in Jeyifo) to Nwosu's declaration on "The Fourth Stage" and Ogun that Soyinka's theorization "is among the earliest African theories on conventional criticism of text" (29) and "marks a major paradigm shift towards textual criticism" (121). Below is the excerpt of what Jeyifo calls "canonical" concerning the Yoruba pantheon as it appears on pages 224-5 of The Interpreters; the emphasis is Jeyifo's and portrays Soyinka's direct application of the mythopoesis in his narrative:

And these floods in the beginning, of the fevered fogs of the beginning, of the first messenger, the thimble of earth, a fowl and ear of corn, seeking the spot where a scratch would become a peopled island; of the first apostate rolling the boulder down the back of the unsuspecting deity [...] and shattering him into fragments which were picked up and pieced together with devotion [...] of the lover of purity, the unblemished one whose large compassion embraced the cripples and the dumb, the dwarf, the epileptic and why not, indeed, for they were creations of his drunken hand and what does it avail, the eternal penance of favoritism and abstinence? Of the lover of gore, invincible in battle, insatiable in love and carnage, the explorer, path-finder, protector of the forge and the creative hands, companion of the gourd whose crimson-misted sight of debauchery set him upon his own and he butchered them until the bitter cry pierced his fog of wine, stayed his hand and hung the sword, foolish like his dropped jaw [...] of the parting of the fog and the retreat of the beginning, and the eternal war of the first procedure with the long sickle head of chance, eternally mocking the pretensions of the bowl of plan mocking lines of order in the ring of chaos [...]. (Jeyifo 26)

It is Jeyifo's stance that Soyinka has appropriated aspects of Ogun motifs for use in the propagation of his art, identity, message, and symbolic constructions and goes on to mention essays with the Ogun "self-fashioning": "The Fourth Stage", "Morality and Aesthetics in the Ritual Archetype", and "The Credo of Being and Nothingness". For the imaginative works, he lists "Idanre"; Ogun Abibiman; and the plays A Dance of the Forests, The Road, and The Bacchae of Euripides, saying that "all entail strong thematic and emblematic foregrounding of this structure of self-invention through the Ogun motifs" (27).

Soyinka is neither new nor alone in this inventiveness for message and change. Bryce (7) cites Soni Labou Tansi and Veronique Tadjou, who find expression in the "mythical register" where in beauty there is "capacity for magical transformation" of their female characters. She makes it more poignant: "Through [...] mythical devices Tadjo, Tansi, and others satirize and destabilize patriarchal power, suggesting through their destructive feminine archetypes the obverse of victimhood and abjection". The strength of an instructive past and what it could do for a positive future is reiterated in Godfried Asante and Gloria Pindi's "(Re)imagining African futures" as such: "Black Panther draws on the past to show the audience what constrains Black imaginations of emancipation and to offer possibilities for the future" (222). More specifically, in "Wakanda Africa do you see?", Elisabeth Osei pinpoints the use of authentic and verifiable African elements of the past such as writing systems, architecture, and feminism in Black Panther as she emphasizes that "the idea of reifying the past to theorize the future is, in fact, a characteristic feature of Afrofuturism" (382). Mention is also made of an uncannily similar force such as Ogun's in the secret ritual of Mevoungou in the film Les Saignantes by Jean-Pierre Bekolo. Mevoungou is described as "neither a living thing nor an object [...] You don't decide to see Mevoungou, Mevoungou appears to you [...] invites itself. Mevoungou cast its spell on us" (Mollo Olinga qtd in Bryce 8). Bryce continues, "If traditionally Mevoungou was an alternative source of power evoked at times of acute national crisis, in the world of the film it is more ambiguous [...] with the potential for both destruction and transformation" (8). In these lines parallels are to be drawn to Ogun's traditional and contrived forms.

Soyinka's attachment to his Ogun transcends fiction and art to his own life and person. Many incidents dot the landscape of his life where the impulsive quirk to forcefully, if need be, but more radically, mostly, change the status quo and shake the veils of complacency in the original manner of forging the path through the fourth stage. It is important to remember that the spiritual journey and pilgrimage that Soyinka undertakes towards his epiphanies of the fourth stage mysteries was while in company of Ogun ("Idanre"). As such, when he shouts 
"Ogun, comrade, bear witness how your metal is travestied!" (qtd in Jeyifo 23) in silent rage to invoke the wrath of Ogun while being shackled in the cell in The Man Died, we cast our minds back to a bond already forged. Jeyifo reminds us that that "is only one of the numerous instances in his writings in which Ogun and many other alter egos, surrogates and 'doubles' of the self are invoked [...]" (23). An uncanny twist is narrated by Ofeimun when he paraphrases Jeyifo, saying that Soyinka's winning of the Nobel Prize with its attendant joy and excitement coincided with the horror and grief of "petrifying events": the murder of Dele Giwa through the parcel bomb and Mozambican President Samora Machel's death in a plane crash-a quintessential portrayal of Ogun's creator and destroyer construct. It is Isidore Okpewho who delivers the clincher:

No doubt that it is becoming increasingly clear to us that the tragic element which Soyinka sees in the African character has been projected largely through his own experience, and that in the end the tormented figure of the Yoruba god, Ogun, which Soyinka has constantly presented to us cannot be separated from the trouble-torn personality of our poet-dramatist (qtd in Jeyifo 29).

\section{The Nietzsche nexus and other conflations}

The semi-experimental backdrop of the fourth stage which births Soyinka's Ogun invention is an abode made of ether in the African worldview. The existence of this phase is not a new discovery as ancient African civilizations and communities have always had an "unnamed" place that permeates, pervades, and surrounds the spaces between the abode of the dead, of the living, and the unborn — becoming substantially the "fourth" stage. Soyinka's concern with this configuration lies in the idea that, for creation or procreation to occur, there has to be a degree of initial distortion of fundamental components or elements of the creative mix. This inevitable chaos, dissolution, and reaggregation is found in the dynamics of the fourth stage in his "Fourth Stage" and the eventual emergence of the victorious Ogun. Soyinka uses as model Nietzsche's antithetical construct of pitting the creator, the plasticizing god Apollo, against the controlling god of non-plastic art, music, and poetry, Dionysos, in his The Birth of Tragedy. In Soyinka's version in "The Fourth Stage", Obatala is the god of creation, effectively pitted against Ogun of poetry, creativity, and destruction. Nietzsche apparently tweaked and bent the Greek gods' myth to his speculative will, and it is safe to say that Soyinka emulated his structure. Ofeimun captures this thus: "Just as Nietzsche felt free to bend Greek gods to his will, Soyinka felt free to bend the Yoruba gods to his will as a way of engaging spheres of experience in which neither science nor Christianity had any explanatory force" (57). As the gods in Nietzsche's construct function in the chthonic realm, Soyinka's fourth stage is also a region in the mythic space where "all the agonies of gods and humankind are experienced, transformed and re-inscribed for the fortification of human will" (Ofeimun 101). Slivers of the speculative give rise to these extrapolations posited by Layiwola in his description of the fourth stage: "The intractable fourth stage which is the resolution ground for imaginative action, dreams, comas, twilight, the loss of consciousness and the split movements just before a birth or just before a death. Even death and mythologies are aspects of the fourth area of experience" (27). The fluidity and intractability of this zone necessitates Soyinka's plethora of adjectives towards its comprehensive description in in Art, Dialogue and Outrage: "universal womb" (27), "transitional abyss" (23), "transitional ether" (24), "infernal gulf" (25), "vortex of archetypes" (26), "metaphysical abyss" (27), "matrix of cosmic creativity", "universal oneness", "the unconscious", "the deep black whirlpool of mythopoeic forces" (29), "chthonic realm" (30), "world womb", "chthonic lair" (32), etc. Contextual and allied issues are mostly the reason for poetic licenses of creations such as Soyinka's structuring of guiding indices for his art and theorizations and, in some cases ("Idanre" especially, as its violence was indicative of the bloody unrests of pre-civil war Nigeria), beacons and contemporary commentaries. Reasons such as diasporic settlements of a collection of ethnicities (such as the slave settlements and their descendants in the Caribbean) giving rise to new myths and hybrid pantheons, and epistemological backgrounds giving room for contextual exigencies, are among the reasons for (a) new religious and mythological order(s). Reverence and recognition, and of course veneration and worship (of deities), all depend on extenuating factors: be they cultural and/or religious survival in a strange land or nationalistic socio-literary re-presentation by cultural champions and academic pundits. Other reasons for poetic licenses of creation include the required or desired construct for handling portrayals of horrors such as genocide. Bryce makes a case for such choices, methods, and inventions with Veronique Tadjo's Shadow of Imana about Rwanda after the genocide which she captures in a travelogue. She combines non-fictional techniques of "observation and reportage with fictional elements like interiority, focalization, and voice [...] (because) sites of genocide [...] challenge her capacity for description and analysis" (6). She has inadvertently birthed in and through the speculative mode, a budding mythopoesis because 
essentially "traditional references provide a narratorial link between an unspeakable actuality and an imaginary alternative" (6). This case is reminiscent of Okri's attempt with Azaro in The Famished Road as the vicissitudes of Nigeria are successfully cast in magical realism. Other examples abound of such experimental speculative fiction which all employ myth, orality, and indigenous belief systems. Post-independence African writers such as Mda, Laing, Okri, Wa Thiong'o, Amadi, Coker, Benjamin Kwakye, and Okorafor are all in the mix of creators and narrators who mix the fantastical with the real in order to handle and interrogate the postcolony.

\section{Conclusion}

The dictum that "new situations demand new magic" (Evans-Pritchard qtd in Comaroff and Comaroff 279) effectively connects with Soyinka's explanations in his 1986 Nobel Lecture for weaving past and present chronos and vice-versa in his works, to the effect of "[it's] not really to indict the past but to summon it, to the attention of a suicidal, anachronistic present [...]" (7). If we reasonably add the future to this construct, a potentially profitable fluidity could even give rise to what Comaroff and Comaroff see as "planetary species whose existence conflates the virtual with the veritable, the cinematic with the scientific, gods with godzillas, the prophetic with the profitable" (283), bringing to mind the awesome cinematic production of the pan-African vision, Black Panther and its kingdom of Wakanda. Such possibilities moor firmly our conviction and application of speculative productions in the form of Africanfuturism to tackle the treacherous terrains of a quicksand-like subversion of the postcolony by heavy and sometimes subtle neocolonial influences. It is clear then that the ability to amalgamate the time phases - present, past, and future - profitably in order to boost our flagging consciousness is an imperative in speculative fiction. Sharper and ever-expanding vertices are encouraged in line with speculative optimism firmly rooted in authentic ontological and archetypal mythological underpinnings. Other stages other than and beyond the fourth stage await. A. A. Adeoye has already suggested a fifth stage-projected as a place of de-robing "mythopoeic lamentations" - in order "to facilitate the attractions and detractions in human existence through the re-creation of true-life stories in coded and elegant theatrical mechanics" (159). This is valid in its right.

Every speculative effort involving real, imagined, and contrived denizens is the budding of a potential mythopoesis. I focus on Soyinka in this article for the far-reaching scope and depth of his re-interrogation, reinvention, and rework of the Yoruba pantheon, the fourth stage and the resultant Ogun. I have explored the implications, imbrications, interpretations, and possible applications of that singular act of creativity bordering on the mythbased fantastic in this essay with attendant multiple critiques indicative of its potential and importance. All these belong to the world of speculative fiction. Fecund imaginations blessed and armed with the deeply epistemological and realistically mytho-cultural umbilicus of peoples and nations roam the creative realm. Liminal margins with multiple creative portals are waiting for implantations of fifth and further stages populated with more Oguns, masks, denizens, ogbanjes, abikus, Mezoungous, Shakas, Ojaadilis, aliens, mami-watas, and their ilk; with care taken to avoid non-domestication and inappropriate rooting of semi-alien religious, mythological and cultural models. ${ }^{1}$ After all, in our realities and alternate realities, our rooted extensions of the other-worldly should be able to give us comfort and companionship so that we can dream about our ancestral masks in peace- $a$ la Achebe $^{2}$

\section{Notes}

1. Akweke Emezi's Freshwater is a good derivation from and a juxtaposition of African folklore and mythology, dealing with the Igbo ogbanje (the nearest equivalent or translation is the changeling) concept linked with the Ala/Ani deity of Gaia dimensions. It also intersects all these with mental health issues of multiple personalities disorder, which is showcased by the protagonist, Ada - the multiple-spirit ogbanje vessel. The narrative is an exemplary construct of the crux of the article.

2. In his "The Igbo World and its Art", Chinua Achebe emphasizes the importance of the process of art against the product itself among the Igbo. He singles out the dance and the masquerade as those that have whetted the Igbo artistic appetite properly. In the masquerade form especially, the concept of process, and therefore motion, is exemplified in dual coda: there is agility and movement in the masquerade display and there is also movement for the spectator who wants to follow the progress fully. This is indicative of the dynamic nexus between the living and the dead. He however bemoans wistfully the decline of many African arts, especially the numinous presences of the ancestral masks and simply declares that "the decline today is merely a symptom of the collapse of a whole eschatology". But as one lucky enough to remain attuned to the ancients and their arts, masks still appear in his dreams with their tell-tale, now ironic "panic terror of childhood". 


\section{Works Cited}

Achebe, Chinua. "The Igbo World and its Art." Hopes and Impediments: Selected Essays 1965-1987. Heinemann, 1988.

Adeoye, A. A. "The Fifth Stage (Beyond the Dirge of Ogun and Soyinka's Romance with the Left)". Kiabara Journal of Humanities vol. 11, no 3, 2005, pp. 155-175.

Adu-Gyamfi, Yaw. "Wole Soyinka’s 'Dawn' and the Cults of Ogun.” ARIEL: A Review of International English Literature vol. 28, no. 4, 1997, pp. 73-89.

Afolayan, Kayode. "Mythology, Aesthetics and Social Vision in Wole Soyinka’s Idanre." The Performer vol. 12, no. 6, 2010, pp. 187-99.

Akporobaro, F. B. O. Introduction to African Oral Literature: A Literary-descriptive Approach. Princeton, 2004.

Alter, Alexandra. "Nnedi Okorafor and the Fantasy Genre She is Helping Redefine." The New York Times. 6 Oct. 2017. https:// www.nytimes.com/2017/10/06/books/ya-fantasy-diverse-akata-warrior.html.

Asante, Godfried \& Gloria Pindi. "(Re)imagining African Futures: Wakanda and the Politics of Transnational Blackness." Review of Communication vol. 20, no. 3, 2020, pp. 220-28. DOI: https://doi.org/10.1080/15358593.2020.1778072.

Bryce, Jane. "African Futurism: Speculative Fictions and 'Rewriting the Great Book'." Research in African Literatures vol. 50, no. 1, 2019, pp. 1-19. DOI: https://doi.org/10.2979/reseafrilite.50.1.01.

Chinweizu, Onwuchekwa Jemie \& Ihechukwu Madubuike. Toward the Decolonization of African Literature. Fourth Dimension, 1980.

Christion, Valley. "Science-Fiction: Defining a Sprawling Genre." The Artifice. 11 Nov. 2018. https://the-artifice.com/sciencefiction-genrel.

Comaroff, Jean, \& John Comaroff. "Occult Economies and the Violence of Abstraction: Notes from the South African Postcolony." American Ethnologist vol. 26, no. 2, 1999, pp. 279-303. DOI: https://doi.org/10.1525/ae.1999.26.2.279.

Delaney, Samuel. "The Mirror of Afrofuturism." Extrapolation vol. 61, no. 1-2, 2020, pp. 173-84. DOI: https://doi.org/10.3828 extr.2020.11.

Dieke, Ikenna. The Primordial Image: African, Afro-American, and Caribbean Mythopoetic Text. Peter Lang, 1993.

Ebeogu, Afam. "From Idanre to Ogun Abibiman: An Examination of Soyinka's Use of Ogun Images." Journal of Commonwealth Literature vol. 15, no. 1, 1980, pp. 85-96. DOI: https://doi.org/10.1177/002198948001500108.

Emezi, Akweke. Freshwater. Grove, 2018.

Hamilton, Elizabeth. "Analog Girls in a Digital World: Fatimah Tuggar's Afrofuturist Intervention in the Politics of 'Traditional' African Art." Nka: Journal of Contemporary African Art no. 33, 2013, pp. 70-9. DOI: https://doi. org/10.1215/10757163-2352821.

Jeyifo, Biodun. Wole Soyinka: Politics, Poetics and Postcolonialism. Cambridge U P, 2004. DOI: https://doi.org/10.3366/ afr.2004.74.4.693.

Katrak, Ketu. Wole Soyinka and Modern Tragedy: A Study of Dramatic Theory and Practice. Greenwood, 1986. DOI: https://doi. org/10.1017/s0307883300014619.

Lawuyi, Olatunde. "Ogun: Diffusion across Boundaries and Identity Constructions." African Studies Review vol. 31, no. 2, 1988, pp. 127-139. DOI: https://doi.org/10.2307/524422.

Layiwola, Dele. "The Philosophy of Wole Soyinka's Art." Journal of Dramatic Theory and Criticism 1996, pp. 19-42.

Mbiti, John. African Religions and Philosophy. Heinemann, 1969.

Niven, Alastair. "Elechi Amadi obituary." The Guardian. 22 Aug. 2016. https://www.theguardian.com/books/2016/aug/22/ elechi-amadi-obituary.

Nwosu, Canice. Postmodernism and Paradigm Shift in Theory and Practice of Theatre. Eagleman, 2014

Ofeimun, Odia. In Search of Ogun: Soyinka in Spite of Nietzsche. Hornbill House of the Arts, 2014.

Ogunba, Oyin. The Movement of Transition: A Study of the Plays of Wole Soyinka. Ibadan U P, 1975.

Okorafor, Nnedi. “Africanfuturism Defined." Nnedi's Wahala Zone Blog. 19 Oct. 2019, http://nnedi.blogspot.com/2019/10/ africanfuturism-defined.html.

Okoro, Dike. "Futuristic Themes and Science Fiction in Modern African Literature." Routledge Handbook of Minority Literatures, edited by Tanure Ojaide \& Joyce Ashuntantang. Routledge, 2020, pp. 379-91. DOI: https://doi. org/10.4324/9780429354229-34.

Osei, Elisabeth. "Wakanda Africa do you see? Reading Black Panther as a decolonial film through the lens of the Sankofa theory." Critical Studies in Media Communication vol. 37, no. 4, 2020, pp. 378-90. DOI: https://doi.org/10.1080/15295036.2020. $\underline{1820538 .}$.

Rosenberg, Donna. World Mythology: An Anthology of the Great Myths and Epics. $2^{\text {nd }}$ edition. NTC, 1994.

Soyinka, Wole. Art, Dialogue and Outrage: Essays on Literature and Culture, edited by Biodun Jeyifo. New Horn, 1988. Myth, Literature and the African World. Cambridge U P, 1976.

. "Nobel Lecture 1986: This Past Must Address Its Present." Cambridge University Press. 23 Oct. 2020. https://www. cambridge.org/core/journals/pmla/article/abs/nobel-lecture-1986-this-past-must-address-its-present/61C434CB0E32F1D B61C6E3F01EA6B087.

Squire, James \& Barbara Squire. Greek Myths and Legends. Glencoe McGraw Hill, 1967.

Womack, Ytasha. Afrofuturism: The World of Black Sci-Fi and Fantasy Culture. Lawrence Hill, 2013. 